\title{
Measurement of Riverbank Erosion Rates of Pusu River Using Erosion Pins Method
}

\author{
Nur Aqilah Mohd Rosli ${ }^{1}$, Saerahany Legori Ibrahim ${ }^{1 *}$, Rabitah Handan ${ }^{2}$, Md \\ Noor Salleh ${ }^{1}$
}

${ }^{1}$ Department of Civil Engineering, Kulliyyah of Engineering, International Islamic University Malaysia (IIUM), 53100 Gombak, Selangor, MALAYSIA

${ }^{2}$ Department of Engineering, Faculty of Engineering and Life Sciences, Universiti Selangor, 40000 Shah Alam, Selangor, MALAYSIA

*Corresponding Author

DOI: https://doi.org/10.30880/ijie.2021.13.03.017

Received 20 December 2020; Accepted 01 May 2021; Available online 06 June 2021

\begin{abstract}
Riverbank erosion is a major concern in all parts of the world due to its extensive impacts geomorphologically and economically. This study aims to quantify the rates of riverbank erosion of Pusu River using erosion pins method. Two sections of the river were selected namely site A and site B where site A is a straight section while site B is situated on the outside bend. 21 pins were installed at each site in a grid pattern. Measurement of erosion pins exposure were taken from February 2019 to April 2019. Field observation were made to identify the possible factors influencing the bank erosion. The average rates of bank erosion ranged between $0.05 \mathrm{~cm} /$ day to $0.21 \mathrm{~cm} /$ day at site $\mathrm{A}$ and $0.09 \mathrm{~cm} /$ day to $0.51 \mathrm{~cm} /$ day at site $\mathrm{B}$. Bank failure occurred at site B towards the end of measurement period due to high flow after heavy rainfall event. Field observations suggest that rates of riverbank erosion were influenced by several factors such as the flow velocity and vegetative cover of the bank.
\end{abstract}

Keywords: Riverbank erosion, erosion pins

\section{Introduction}

Riverbank erosion is a process of removal of earth materials from the bank of a river [1]. Although it is a natural process; it can be accelerated through human impact causing serious loss of topsoil. The rate of erosion that happen all over the world has increased tremendously due to human activities such as land clearing. The rate of erosion can be influenced by numerous factors such as vegetation [2], flow velocity [3]-[4], soil structure [3], and precipitation [5]. Malaysia's climate is categorized as tropical rainforest which is characterized as having high temperature and humidity throughout the year and thus is frequently associated with soil erosion [6]. Pusu River was chosen to be the study area due to several reasons. Firstly, significant amount of bank erosion and sedimentation was spotted along the bank of Pusu River. In addition, there have been only few studies conducted on bank erosion of Pusu River. To design a suitable erosion control, it is an utmost important to identify the rate of erosion of the riverbank and the factors contributing to the riverbank erosion. A wide range of methods and techniques to measure rate of riverbank erosion have been introduced by previous research. Data required to analyze riverbank erosion can be obtained through field measurement such as erosion pins, bank profiling, topographic maps, aerial photograph, and sedimentary and biological evidence [7]. The aim of this study is to quantify the riverbank erosion rates of Pusu River using erosion pins method and identify the severity of the erosion. Erosion pins is an economical and widely employed technique to acquire short- 
term, detailed erosion data. The advantages of using erosion pins were emphasized in several publications. The method was found to be an effective and efficient field measurement method as it can be conducted without using any special equipment. Besides that, erosion pins have higher sensitivity where it can measure small amount of bank retreat [8]. Field observations were also conducted to understand the process of bank erosion at the site and factors that influenced the rate of bank erosion.

\section{Materials and Method}

\subsection{Study Area}

Pusu River has a drainage area of $12.4 \mathrm{~km}^{2}$ and flows through International Islamic University Malaysia (IIUM) before it joins Gombak River. According to the National Water Quality Standard for Malaysia, Pusu River is now categorized as Class IV river which is equivalents to the worst river condition [9]. One of the major factors affecting the river water quality is the sand mining and land clearing activities that are happening at the upstream of the Pusu River. Uncontrolled land clearing activities have been carried out for years along the tributaries of Pusu River for the purpose of residential development. The exposed land surfaces were eventually eroded and washed into the river. Riverbank erosions were spotted along the bank of the river. Distinctive evidence of sedimentations was also observed along the river network. Fig. 1 shows the selected sections of the river named site A and site B. Two sections of the river with different morphology were selected to compare the rates of bank erosion at both sections. Site A is a straight bank section with some vegetation cover while site B is located at a bend section where the bank surface is partially bare and actively eroding. The length of each section is approximately seven meters. The geographical coordinates of the section of the river is 3814'59.8'N $101843^{\prime}$ '56.7' $\mathrm{E}$ for site A and 38 14'59.07'N 101843'57.75' E for site B.

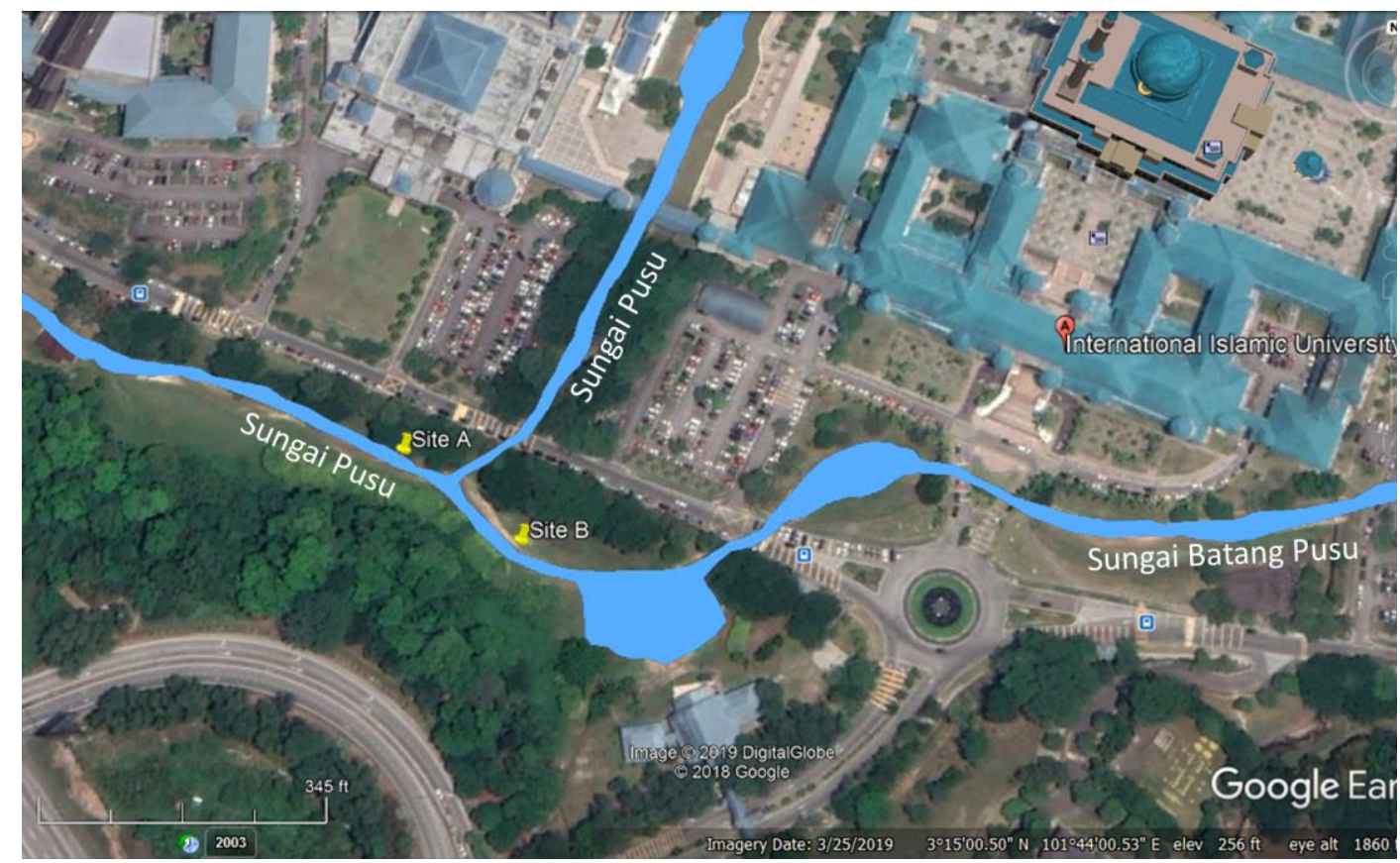

Fig. 1 - Location of the study sites along Pusu River

\subsection{Erosion Pins}

21 pins were installed at each site in a grid pattern at equal interval of one meter apart along the bank as recommended by Thorne [10] and spaced vertically about $15 \mathrm{~cm}$ apart. Each site consists of seven plots with three pins at each plot. The pins are made up of mild steel rod with diameter of $6 \mathrm{~mm}$ and length of $60 \mathrm{~cm}$. The length of the pins depends on the expected rates of erosion and frequency of site visits. Needlessly long pins may reinforce the bank and causes block failure while short pins are susceptible to pin loss and thus, it is crucial to maintain the ideal pin length [10]. Installation of the rods was done using hand pressure and pliers alone as suggested by Lawler [8]. The rod was inserted perpendicular to the bank until only $15 \mathrm{~cm}$ from the total length of the pin remains visible. The end of each pin was labelled by numbers to facilitate the pin measurement. According to Hooke [7] and Thorne [10], erosion pins are much suited for bank composed of alluvial materials and are not recommended for gravel materials. 


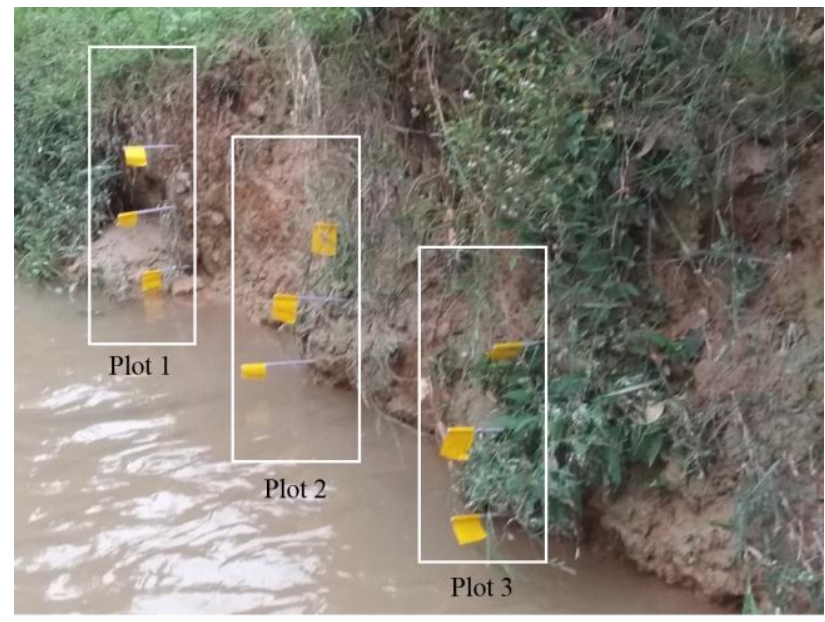

Fig. 2 - Erosion pins installed at plot 1 until plot 3 of site B

Fig. 2 shows the erosion pins installed at plot 1 until plot 3 of site B. Erosion pins exposure were measured approximately four times a week and after every rainfall event. The rate for each plot was measured starting from February 2019 to April 2019. Measurements were taken from the tip of the rod to the bank surface to account for material removal. Pin resetting was done after each storm event to avoid loss of pin. Field observation were also made to identify the factors affecting the rates of bank erosion.

\subsection{Cross-section Profile}

Measurements of depth and width of the river sections were taken to establish the cross-section profile of the site study. Survey tape and pole were found to be sufficient to be used as the river channel is narrow and shallow. Crosssection profile does not provide sufficient data needed to assess bank retreat accurately. However, it can be used to observe the net change in channel width and depth and provide and insight on the process of erosion and sedimentation happening at that sections.

\section{Results and Analysis}

The average rate of bank erosion for each plot was calculated by summing up the total amount of erosion for every measurement and dividing it by period of measurement. The average rates of bank erosion measured by erosion pins are presented in Table 1.

Table 1 - Average rates of bank erosion measured by erosion pins

\begin{tabular}{lcccccccc}
\hline & \multicolumn{6}{c}{ Average rates of bank erosion (cm/day) } \\
\cline { 2 - 8 } & Plot 1 & Plot 2 & Plot 3 & Plot 4 & Plot 5 & Plot 6 & Plot 7 \\
\hline Site A & 0.10 & 0.21 & $-0.16^{\mathrm{a}}$ & 0.05 & $-0.03^{\mathrm{a}}$ & 0.21 & $-0.13^{\mathrm{a}}$ \\
Site B & 0.34 & 0.21 & 0.33 & 0.51 & 0.39 & 0.10 & 0.22 \\
\hline
\end{tabular}

The data showed that out of 7 plots at site A, 4 plots undergone net erosion while 3 other plots undergone net deposition. Meanwhile, all the plots at site B have undergone net erosion. The average rates for each plot range from $0.05 \mathrm{~cm} /$ day to $0.21 \mathrm{~cm} /$ day at site A and $0.09 \mathrm{~cm} /$ day to $0.51 \mathrm{~cm} /$ day at site B. It can be seen from Table 1 that some of the rates are considerably high. This was mainly due to several series of heavy rainfall events that occurred over the period of measurement which causes high amount of erosion and bank failure at the site. After each heavy rainfall event, the flow of the river is higher, thus the river velocity also increases and has more kinetic energy causing more erosion to the riverbank. Initially, the length of the pin protruding was set to be $15 \mathrm{~cm}$, however, after heavy rainfall event, the length of the pin protruding measured can be up to $25 \mathrm{~cm}$.

A comparison of the rates from Pusu River with other published rates denotes that the rates are not significantly high and similar rates have also been measured in other locations. Table 2 shows the comparison between published mean bank erosion rates and the rates obtained for Pusu River. 
Table 2 - Comparison between published mean rates of bank erosion and Pusu River

\begin{tabular}{lll}
\hline \multicolumn{1}{c}{ River } & Period of Measurement & \multicolumn{1}{c}{$\begin{array}{c}\text { Mean Bank Erosion Rate } \\
(\mathbf{m} / \mathbf{y r})\end{array}$} \\
\hline Exe River [7] & January 1974 - June 1976 & $0.08-1.18$ \\
Daintree River [11] & $2004-2006$ & 0.073 \\
Torrens River [12] & $1960-1963$ & 0.58 \\
Pusu River & February 2019 - April 2019 & $0.183-1.86$ \\
\hline
\end{tabular}

The data from this research was compared with published mean bank erosion rates that uses erosion pins method. The table suggests that the rates from Pusu River fall within the general distribution and are consistent with results from other previous studies.

Amount of sediment erosion measured using this method are slightly higher compared to other methods as erosion pins method is a short timescales technique to measure erosion rates. Generally, the longer the period of measurements, the lower the rates of erosion obtained [7]. Erosion rates measured using long timescale technique such as sedimentological evidence, botanical evidence, historical sources, map, and aerial photograph are normally lower. Besides that, the results obtained using erosion pins method are highly influenced by the magnitude-frequency of events. The amount of erosion caused by the occurrence of infrequent heavy storm events can affect the average erosion rates measured greatly.

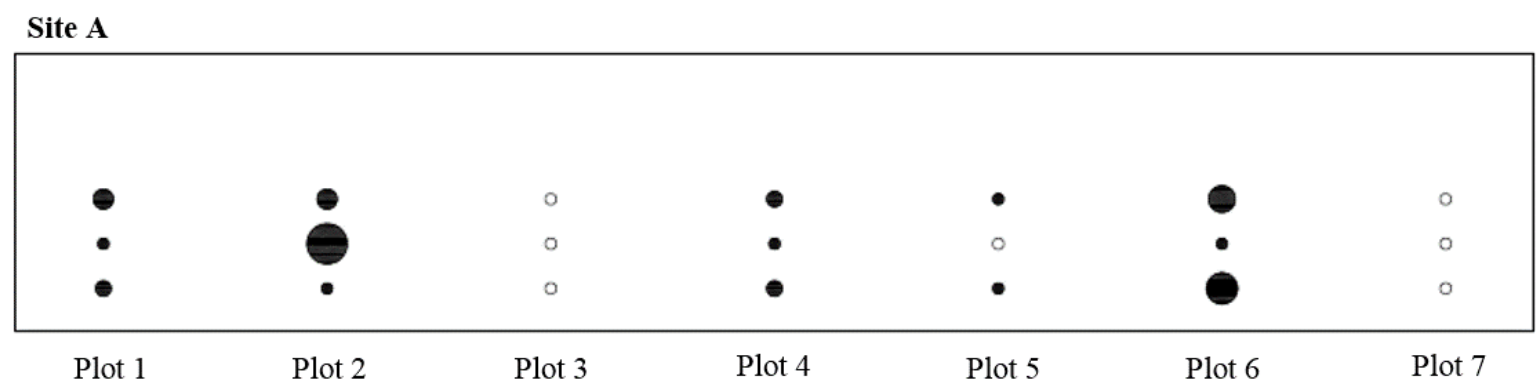

Site B

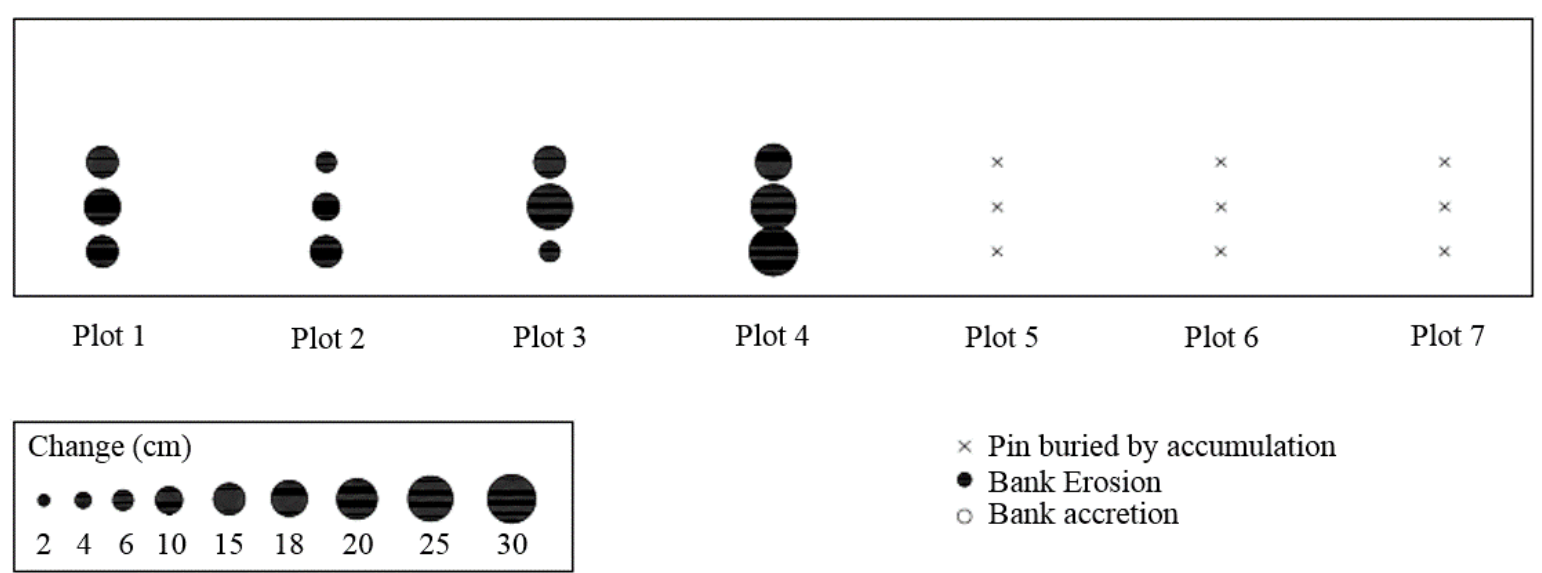

Fig. 3 - Spatial variation of bank erosion at the end of measurement period

The bank erosion rates with respect to each pin for both sites at the end of measurement period were represented in the spatial variation shown in Fig. 3. The bank erosion rates were illustrated by proportional circle representation of erosion pin data. The size of the circle represents the change in erosion pin length over the period of measurement. The maximum erosion at site A can be found at plot 2 and 6 with the highest pin net change value of 15.70 and $20.70 \mathrm{~cm}$. Plot 3, 5 and 7 of site A were experiencing deposition and it was observed that there is also an increase in the density of vegetation at these plots. Although it was hard to identify the exact cause of aggradation at these plots, there are some possible causes which include deposition of sediment during high flows, soil expansion, as well as parallax error when the readings were taken. Based on field observation, after every heavy rainfall event, bank sections without riparian vegetation will undergo net erosion while bank section with riparian vegetation will undergo net deposition. The vegetation may have trapped the coarse sediments that are deposited at the bank during high flow. Site B was found to be experiencing more erosion compared to site A Plot 3 and 4 at site B recorded the highest pin net change value of 
27.30 and $30.20 \mathrm{~cm}$. Bank failure was also found at site B after 47 days since installation of pins where 9 out of 21 pins at the site were buried by accumulation. Site B which is situated on the outside bend undergone massive erosion as the results of high flow velocity directed to the bank. Due to high amount of soil deposited at the site after heavy rainfall event, there is a significant difference in the depth of the river over the period of measurement.

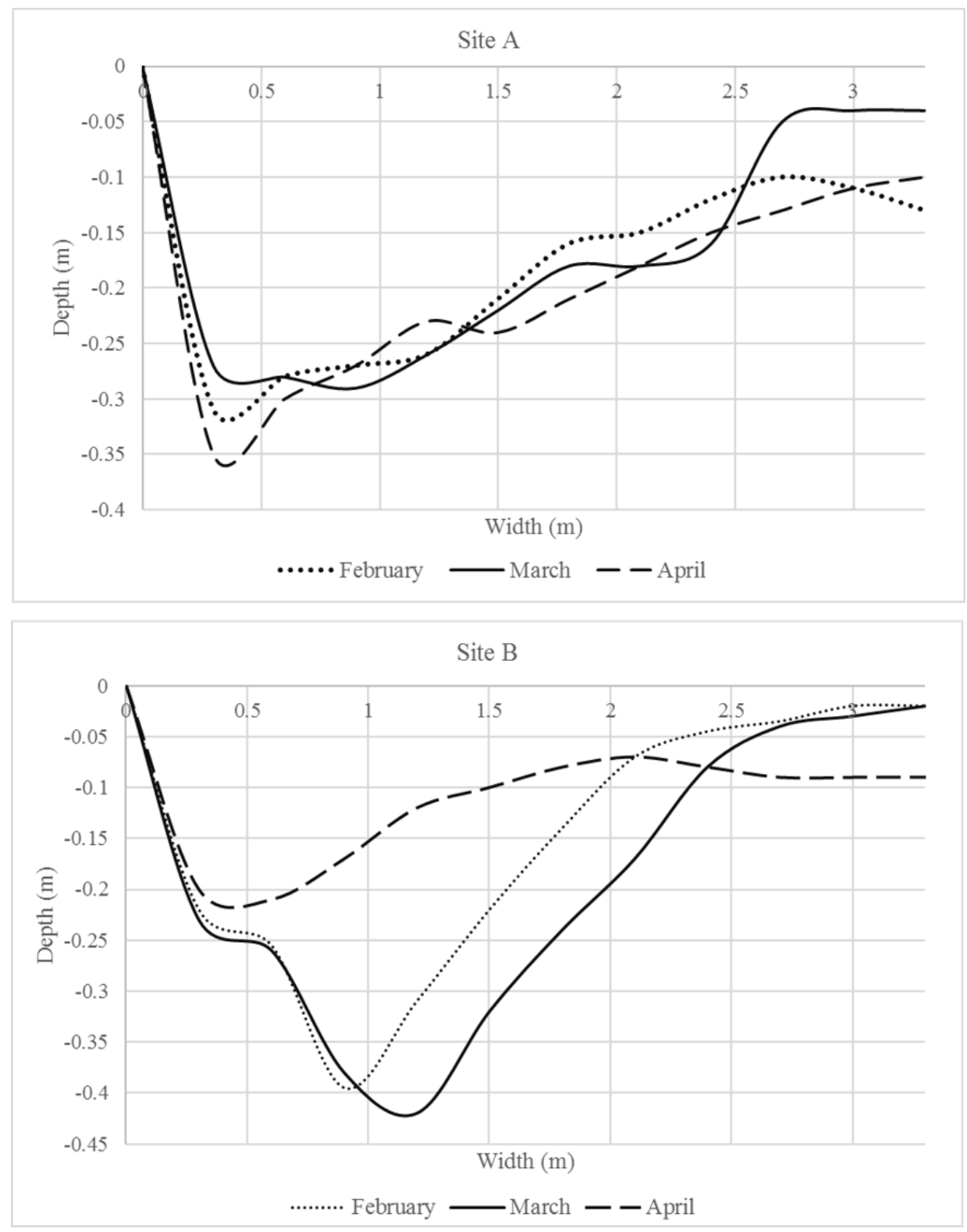

Fig. 4 - Cross section profile of site A and site B from February 2019 to April 2019

Fig. 4 shows the cross-section profile measured at site A and site B over the three month of measurement period. Subtle changes in channel depth can be seen at site A over the three months where the depth increases from February until April. Based on field observation, the depth of river increases after heavy rainfall event due to basal erosion. The right side of the channel is shallower as deposition of sediment occurs here while erosion occurs at the left side of the channel. There was a small change in depth between month of February and March at site B. However, an abrupt change in depth can be seen in the month of April after heavy rainfall event. Huge amount of sediment was deposited at the site after the heavy flow, causing the depth of river to decrease significantly. The pattern of the cross-section profile for all three months were the same where the outside of the bend was considerably deeper compares to the inside of the bend where decomposition of sediments occurs. However, the trend of site A and site B were contradicted where the channel depth at site A increases over the period of measurements while the channel depth at site B decreases. This was mainly due to the series of heavy storm events that occurred at the end of March 2019 until end of April 2019. Both sites recorded higher erosion rates in this period as reflected in the cross-section profile of site A where the channel depth increases due to basal erosion. On the other hand, bank failures occurred in site B causing the bank materials to enter the river and deposited at the bed. 


\section{Conclusion}

The average bank erosion rates measured using the erosion pins over the period of approximately three months range from $0.05 \mathrm{~cm} /$ day to $0.51 \mathrm{~cm} /$ day. Series of heavy rainfall event had occurred over the measurement period resulting in high amount of erosion and bank failures which caused loss of pins. Field observation suggests that rates of riverbank erosion was influenced by several factors such as the flow velocity and vegetative cover of the bank. It was also identified that the rates of riverbank erosion were higher on the outside bend section compared to the straight section. The rates obtained from this study was not significantly high and similar rates had also been measured in other locations. However, some plots exhibit considerable amount of erosion that may cause problems in the long run. Thus, implementing preventative actions need to be taken into consideration.

\section{Acknowledgement}

This research was financially supported by Fundamental Research Grant Scheme for Research Acculturation of Early Career Researches (FRGS-RACER) Research Project (RACER19-051-0051) entitled "Formulation of Empirical Equation for Quick Riverbank Erosion Prediction”.

\section{References}

[1] Chatterjee S. \& Mistri, B. (2013). Impact of riverbank erosion on human life: A case study in Shantipur Block, Nadia District, West Bengal. International Journal of Humanities and Social Science Invention, 2(8), 108-111

[2] Pimentel D. (2006). Soil erosion: A food and environmental threat. Environment, Development and Sustainability. 8, 119-137

[3] Watson A. J. \& Basher L. R. (2006). Stream Bank Erosion: A Review of Processes of Bank Failure, Measurement and Assessment Techniques, and Modelling Approaches Report No.2005-2006/01. Nelson

[4] Rinaldi M. \& Darby S. E. (2007). Modelling riverbank erosion process and mass failure mechanisms: Progress towards fully coupled simulations. Gravel Beds Rivers VI from Process Understanding to River Restoration, 231 258

[5] Wolman M. G. (1959). Factors influencing erosion of a cohesive bank. American Journal of Science, 257 204-216

[6] Abidin R. Z., Sulaiman M. S. \& Yusoff N. (2017). Erosion risk assessment: A case study of the Langat riverbank in Malaysia. International Soil and Water Conservation Research, 5, 26-35

[7] Hooke J. M. (1980). Magnitude and distribution of rates of river bank erosion. Earth Surface Processes, 5, 143157

[8] Lawler D. M. (1993). The measurement of riverbank erosion and lateral channel change: A review. Earth Surface Processes and Landforms, 18, 777-821

[9] Nuruzzaman M., Al Mamun A. \& Salleh M. N. (2015). Upgrading of small sewage treatment plants for ammonia removal - case of a university campus. ARPN Journal of Engineering and Applied Sciences, 10(23), 1739117396.

[10] Thorne C. R. (1981). Field measurement of rates of bank erosion and bank material strength. Erosion and Sediment Transport Measurement, 133, 503-512

[11] Bartley R., Keen R. J., Hawdon A. A., Disher M. G., Kinsey-Henderson A. E. \& Hairsine P. B. (2006). Measuring Rates of Bank Erosion and Channel Change in Northern Australia: A Case Study from The Daintree River Catchment CSIRO Land and Water Science Report. Commonwealth Scientific and Industrial Research Organisation, pp. 16-28

[12] Twidale C. R. (1964). Erosion of alluvial bank at Birdwood, South Australia. Zeitschriftfur Geomorphologie, 8, 189-211 